\title{
Modeling the Behaviour of Corporate Demand for Credit in Mauritius before and after the Global Financial Crisis Under Conditions of Excess Liquidity by Banks
}

\author{
Chakeel Coomar Prayagsing \\ Finance Manager, Mauritius
}

\begin{abstract}
This Paper proves that the global financial crisis (GFC) has had a major influence in altering the pattern and subsequent demand for corporate finance in Mauritius. By applying probability models, it is found that bonus issuance is a key factor that influences the demand and supply for both debt and equity financing. Firms consider debt repayment variable of upmost essence to loan application and provision responses. Large companies, comprising of entities falling under the wing of the manufacturing, industrial and retail sector found ease in obtaining bank loans prior to the crisis due to the positive rating and nature of their respective businesses. Conversely, small and medium enterprises found themselves relaying heavily on startup loans, of limited amounts, as they failed to qualify for greater loan applications due to their inability to meet the adequate requirements. Corporate entities on their end, had a much greater preference for equity financing prior to the crisis. The aftermath of the crisis nevertheless negatively influenced the pattern of financing for all categories of businesses. A more regulated framework was adopted by banks, on an international level which caused banks to be more cautious and limited in providing finance to entities. Even with excess liquidity, banks have declined demand for bank loans.
\end{abstract}

Keywords: Global Financial Crisis, Corporate Finance, Probability Models, Mauritius, Excess Liquidity.

\section{INTRODUCTION}

One important gap in the present literature is an understanding of how firms adjust their demand for credit in the aftermath of the GFC. It is thus crucial for policy makers to clearly understand this behaviour in order to adopt conducive policies to assist them in periods of stress. Important insights on this can be generated from understanding the microeconomic adjustment of firms seeking external funds as well as the features of successful applicants for bank loans. It is important to understand whether the GFC results to structural change in the company, such as decrease in demand, or tightening of credit in the market. Firms which are financially constrained internally must resort to the external market in order to implement a viable investment project. However, these firms become even more constrained with external shocks in the financial system caused by the GFC (see Mach and Wolken, 2012). 
Prayagsing, C. C. (2020) Modeling the Behaviour of Corporate Demand for Credit in Mauritius before and after the Global Financial Crisis Under Conditions of Excess Liquidity by Banks Archives of Business Research, 8(5). 63-79.

The GFC is expected to influence both the demand and supply of funds in the economy (see Udell, 2009 and Haasbroek, 2017). From a supply perspective, providers of credit become more conservative in their approaches (e.g., Honohan, 2009) and therefore make a lower amount of credit available to firms. From a demand for debt standpoint, firms suffering from the impact of the financial crisis such as a decline in the demand for their products and services tend to either demand lower funds from banks or increase their demand to ensure business growth/survival. By and large, they delay investment projects and often deleverage.

Innovatively, this Paper also analyses the impact of excess liquidity by banks on the demand for funds by companies. It is expected that excess liquidity induces banks to increase their supply of loans. It analyses the features of firms applying for bank loans both before and after the GFC and investigates whether bank refusal for loans in a previous period discourages firms from reapplying in the next period. As such, two distinct models of firms' demand for credit both, before and after the GFC, is developed and empirically tested with a Probit model.

\section{REVIEW OF LITERATURE - CHOICE BETWEEN DEBTS AND EQUITY}

The foundation of corporate demand for credit is based mainly on their capital structure, that is, their choice between either the use of either debt or equity financing (see Hamid and Singh, 1992) in order to maximize their worth. Durand (1959) showed that firms used debts in order to influence the value of their Weighted Average Cost of Capital. This was later challenged by Miller and Modigliani (1958 and 1961) who illustrated that firms do not really bother on the mixture of corporate debts and equity as this does not impact on shareholders wealth. Under the Static TradeOff theory (Myers, 1984)., firms make more use of external debts because they benefit from taxation gains from interest paid on debts. However, they also monitor the probability of corporate bankruptcy with debts and hence may limit the usage of same.

Based on the principle of information asymmetry, Myers and Majluf (1984), Stiglitz and Weiss (1981) propounded the Pecking Order Hypothesis of Capital Structure. It argues that the problem of information asymmetry creates a hierarchy of priorities that firm follow in their financing strategies. For any new investments, they use retained earnings as a priority as the latter entail lower or no information asymmetry. After retained earnings, they resort to debts, followed by hybrid debts and then ultimately to equity financing, as they entail agency costs. Jensen and Meckling (1976) developed the Agency theories of capital structure, which postulate that the use of debts or equity is determined by the trade-off between the costs of debts and equity. Other authors, such as Ross (1977) showed how debt could be used as a costly signal to separate the good from the bad firms and hence firms tend to use mire debts.

Based on the above literature, several determinants have been put forward to explain the choice of demand for credit. These range from firm specific, market specific, industry specific and macroeconomic factors. Rajan and Zingales (1995) identified three important determinants of corporate leverage: asset tangibility, firm profitability and firm size.

The more collateral available to a firm in terms of assets, the more the firm can take loans and thus a higher leverage. This might however not be possible due to agency costs and pressure by shareholders not to take loans. The overall impact of asset tangibility on capital structure has thus been indeterminate in the literature. Bradley et al. (1984) found a positive relationship between 
asset tangibility and leverage. Results have however varied with the definition of firm leverage (e.g. Jordan et al., 1998).

In general, higher profitability implies that firms can borrow more as they can credibly signal credit institutions of their worthiness. However, because of high transaction costs and market imperfections, they may prefer to use internal finance, as predicted by the POH. Management finds it better to manage internal rather than external funds. Kester (1986) and Myers (1984) found a negative relationship between profitability and leverage. However, the Free Cash Flow hypothesizes that firms which take debts become more disciplined and send a better signal in the market. A positive relationship between leverage and profitability is therefore expected. Moreover, high profitable firms are likely to have high debt ratio in order to obtain attractive tax shields. Other researches have used cash flow as a better indicator of firm profitability.

Economic theory postulates that size brings along economies of scale and firms are expected to increase their leverage. Such economies of scale range from more diversification of risk, lower risk variances and less probability of bankruptcy costs. However, Weston and Brigham (1981) argued that managers of large firms might rather prefer to use more equity in order to reduce agency costs and hence a negative relationship between size and leverage exists. A positive relationship between size and leverage has been found by Barclay and Smith (1996) whereby smaller firms made greater use of equity financing. Yet, Friend and Lang (1988) found an insignificant relationship between these variables. Age of firms is indication of reputation which allows them to access more debts and hence a positive relationship with leverage.

\section{CAPITAL STRUCTURE ANALYSIS OF FIRMS BEFORE AND AFTER THE GFC.}

An analysis of the gearing ratios illustrates that there is a wide variation in the ratio among companies within the same industry. This is mainly explained by the fact that some companies are more diversified than others and have different modes of financing investment projects. Moreover, there is a large variation in the gearing ratio across different industries and a very high volatility of capital structure choice. Almost all industries are highly geared, with the exception of leasing companies, which have low gearing ratios. This may be explained by the fact that such companies finance their activities by leasing payments received and therefore do not take much debts. In contrast, the construction and related industry are the most highly geared companies, implying that they take more debts and issue preferred shares for the financing of their investment activities. This can be explained by the high level of investment needed in such industries whereas the reserves of the company and equity may be used to pay dividend, or for the financing of short-term contingencies.

The overall gearing ratio of firms has shown an increasing trend over the years, implying that most companies in the different industries are employing more long-term debts and preference shares, in relation to their ordinary equity issued and savings. However, an analysis of the mean debt/equity ratios over the years indicates different results. All the firms have high ratios, with an overall increasing trend over the years, indicating that companies are using more and more debts instruments to finance investment activities. The highest ratio is observed in the oil industry while the banking industry observes the lowest debt/equity ratio. 
Prayagsing, C. C. (2020) Modeling the Behaviour of Corporate Demand for Credit in Mauritius before and after the Global Financial Crisis Under Conditions of Excess Liquidity by Banks Archives of Business Research, 8(5). 63-79.

These results are somewhat contrary to that obtained from the gearing ratio of firms. The different results are caused by the interaction of other parameters impacting on the firm's financing decision: preference share issues and firm's equity (reserves and share capital issued). Some firms prefer to deploy their reserves or simply issuing more ordinary share capital in order to finance investment. Leasing companies, for instance, are lowly geared but exhibits high debt/equity ratios, logically implying that these firms have either increased their reserves by declaring lower dividends or decreased the issue of preference shares.

Differences in the two ratios indicate that there is a clear interaction between debt, equity and reserves (indirectly dividends) of these firms. A wide variation in the gearing ratio among companies within the same industry as well as across different industries is noted. High volatility of capital structure choice is also observed and almost all industries are highly geared with increasing gearing ratios. The high gearing ratios in pre GFC could have sent a signal on the bank distress along with the higher risk of loans being provided and the reduction in capacity for banks to absorb these losses.

In the post GFC period, it can be deduced that gearing ratios have been decreasing for all sectors and over the years, though some fluctuations have been noticed. The banking sector, distributive trade and textiles sector had a lower gearing ratio while the leasing and investment sectors were highly geared. During post GFC, the banks had also adopted a financial bottleneck policy whereby they have been reducing credit facilities available, thus firms had to resort to equity in order to raise finance. This in turn led to the decrease in gearing ratios. The investment sector had a highly fluctuating gearing ratio over the years and reached up to $89 \%$ and the same trend was noticed for the oil industry whereby the fluctuation reached $14 \%$ to $89 \%$. Given the period of instability in post GFC, the highly geared sectors such as investment and oil experienced higher fluctuations than the lower geared ones such as banks, insurance and textiles. The higher dependency on external financing and on the other hand the reduced access to credits, were impeding on the highly geared industries over the years, thereby resulting in higher fluctuations.

\section{PROPOSED FRAMEWORK AND MODEL BUILDING}

In this part, two different models of access to corporate finance are built as follows:

\section{Model 1}

\section{Before Financial Crisis}

ACCESS TO FINANCE = Function (LARGESTCOMPANIES/SME, CORPORATE GROUPS, BONUSISSUE, APPLY EQUITY/APPLY LOAN, BANKREJECTS 07 )

\section{After Financial crisis}

ACCESS TO FINANCE = Function (LARGESTCOMPANIES/SME, CORPORATE GROUPS, BONUSISSUE, APPLY EQUITY/APPLY LOAN, BANKREJECTS ${ }_{10}$ )

\section{Model 2}

It is the same equation except that the variable bonus issue is eliminated and replaced by another variable which is debt repayment. 


\section{Before Financial Crisis}

ACCESS TO FINANCE $=$ (LARGESTCOMPANIES/SME, CGROUPS, DEBTREPAYMENT, APPLYEQUITY/LOAN, BANKREJECTS 07 )

\section{After Financial crisis}

ACCESS TO FINANCE $=$ (LARGESTCOMPANIES/SME, CGROUPS, DEBTREPAYMENT, APPLYEQUITY/LOAN, BANKREJECTS 10 )

\section{ECONOMETRIC MODELS}

\section{Model 1}

\section{Before the Financial Crisis}

ACCESS TO FINANCE $_{07}=(\Omega+$ $\alpha C G R O U P S+\pi B O N U S I S S U E+\mu$ APPLYLOAN $/$ EQUITY+

$\rho$ BANKREJECTS $_{07}+\varepsilon$

OLARGESTCOMPANIES+ $\quad$ BSME $\quad+$

\section{After the GFC}

ACCESS T0 FINANCE $_{10}=(\Omega+\theta$ LARGESTCOMPANIES $+\beta S M E+\alpha C G R O U P S+\pi B O N U S I S S U E$ $+\mu$ APPLYLOAN/EQUITY $\rho$ BANKREJECTS $_{07}+\varepsilon$

+ EXCLIQ

(6)

\section{Model 2}

\section{Before the Financial Crisis}

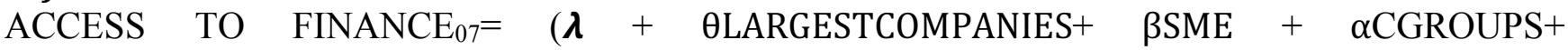
$\pi$ DEBTREPAYMENT $+\mu$ APPLYLOAN/EQUITY $+\rho$ BANKREJECTS $_{07}+\varepsilon$.

\section{After the GFC}

ACCESS TO FINANCE $10=(\boldsymbol{\lambda}+$ OLARGESTCOMPANIES $+\beta$ SME $+\alpha$ CGROUPS $+\pi$ DEBTREPAYMENT + $\mu$ APPLYLOAN/EQUITY $+\rho$ BANKREJECTS $_{07}+\varepsilon$

\section{COLLECTION OF DATA}

The target population of this study are the SME sector and the top 100 largest companies. As such, data has been collected from the financial statements of 300 SMEs available from the Registrar of Companies. Information about their loan portfolio before 2007 and in 2010, as available in their balance sheets, has also been collected. For the SMEs, this data has been collected in a survey undertaken regarding whether they were either successful or unsuccessful in their applications for bank loans in 2007 and in 2010. The sample of firms contained companies in the 7 different sectors, notably banks, insurance, leasing, hotels, manufacturing, retail/distributive trade and the construction sector. The corporate characteristics of these firms, that is whether they were in group structure, SMES or large firms were identified. The variables in this study are defined below.

Access to finance is applied as a proxy to measure the degree of financial constraint of firms. It refers to the capacity of firms to obtain finance, financial services, insurance and other credit facilities for their business, either bank loans or equity. According to Company Act 2001, a firm is usually termed as a large company if it generates a turnover of more than 10 million rupees. In the same vein, firms fall in the category of SMEs if their respective turnover for their financial period is less than 10 million rupees. They also employ fewer employees than the large companies. These 
Prayagsing, C. C. (2020) Modeling the Behaviour of Corporate Demand for Credit in Mauritius before and after the Global Financial Crisis Under Conditions of Excess Liquidity by Banks Archives of Business Research, 8(5). 63-79.

variables are modelled in order to study the ease of access to finance for both large companies and SMEs. A corporate group is a pool of the holding and subsidiary companies where the holding (parent) organization regularly assumes responsibilities for the all the subsidiaries including setting up strategic direction and mission statement of the group. Corporate groups behave like a single economic entity. The underlying reason for including this variable is that subsidiary companies rely heavily upon the parent company for financing and accounting services. Hence belonging to a corporate group usually means greater and easier access to finance from its parent company and affiliates. It is assumed that firms belonging to a corporate have greater access to finance.

Bonus issue is an allocation of additional shares from the company's accrued incomes that are not given out in the form of dividends. These shares are issued in proportion to the shares already held. Hence, this method enables the company to get quick finance especially when it is short of cash. It is the easiest form of financing as company's accumulated earnings can be used for reinvestment, while instead of paying dividends, the company can issue bonus issue to compensate their shareholders. Excess liquidity can be defined as excess funds lying with banks, which allow them to give extra loans. Dividend repayment can take several forms such as cash bonus issue, share repurchase, amongst others. A company is expected to pay dividend at the end of its financial year. However, there are circumstances that investment opportunities might arise to lure managers to forego the repayment of dividends in exchange of higher returns from the investment project. Therefore, foregoing dividend repayment yearly is a form of easy finance. Equity financing is a cheaper source of finance compared to the costs of servicing bank loans. The firm generate cash by issuing shares. However, equity financing implies the danger of losing control of its own firm as the ownership get transferred to the one who hold the majority of shares in the firm. The rationale of choosing between loan and equity financing will depend on the firm's characteristics and the purpose for the finance required.

Loan application is a conventional form of financing for firms, especially for newly start up business who have no retained earnings. However, the cost of servicing a loan can be often quite high. This implies paying for very high interest rate after the loan is granted. This is possible only after full screening of the firms' financial and repayment capabilities. Bank reject means the number of times banks reject loans, prior and after the financial crisis. After financial crisis it is more obvious that banks have rejected loans because of the insufficient capitalization and tighter credit standards of the bank. Hence the results of the rejection of bank loans is expected to be positive after the financial crisis. The variable Bank Reject in 2007 is included also to test for borrowers who were refused a credit application. This is included for the equations of bank loan application in 2010.

\section{METHOD OF ANALYSIS- PROBIT MODEL}

The following section describes the modelling of the variables. The methodology employed is a Probit model where the variables can take only two values, 1 or 0 . The table below gives further details about the modelling of each variables in their respective regression equation. 
Table 1: Definition of the variables

\begin{tabular}{|c|c|}
\hline Variables name & Definition of variables (Probit Estimation) \\
\hline $\begin{array}{l}\text { Apply loan } 2007 \\
\text { Apply loan } 2010 \\
\text { Apply equity } 2007 \\
\text { Apply equity } 2010 \\
\text { Bank success } 2007 \\
\text { Bank Success } 2010 \\
\text { Corporate groups }\end{array}$ & $\begin{array}{c}1 \text { if firm apply for loan; } 0 \text { otherwise } \\
1 \text { if firm apply for loan; } 0 \text { otherwise } \\
1 \text { if firm apply for equity; } 0 \text { otherwise } \\
1 \text { if firm apply for equity; } 0 \text { otherwise } \\
1 \text { if firm loan application is successful; } 0 \text { otherwise } \\
1 \text { if firm loan application is successful; } 0 \text { otherwise } \\
1 \text { if the firm is an affiliate from corporate group; } 0 \text { otherwise. }\end{array}$ \\
\hline Bonus Issue & 1 if the firms issue bonus shares; 0 otherwise. \\
\hline $\begin{array}{l}\text { Bank rejects } \\
\text { Dividend Repayment }\end{array}$ & $\begin{array}{l}1 \text { if a firm applied for, but failed to secure a bank loan in } \\
\qquad 2007 / 2010 ; 0 \text { otherwise. } \\
1 \text { if firm does not dividend on a yearly basis; } 0 \text { otherwise }\end{array}$ \\
\hline
\end{tabular}

Source: Author's work

\section{ESTIMATION STRATEGY AND SECTORAL RESULTS}

A normal distribution is assumed and the different Probit equations are estimated using maximum likelihood estimation (MLE). Empirical results of marginal coefficients of models 1 and 2 are reported in tables 2. Regression coefficients of the models are provided in table 3. For robust results, the Pearson correlation coefficients and variance inflation factors have been calculated to ensure that the variables do not suffer from the problem of multicollinearity.

Seven dummy variables for firms in the different sectors have been included in order to investigate their requests for financing and success in obtaining same both before and after the GFC. Such an analysis is important because, as found in the previous chapters, their capital structure and corporate financing strategies differ. Moreover, it is important to investigate how firms in the different sectors react with their financing patterns with the GFC

Based on econometric models 1 and 2, different hypotheses can be tested. Given the Probit models, the marginal probabilities of demand for bank loans can be inferred on, both before and after the GFC. Moreover, different regression coefficients of the factors determining the demand for bank loans can be deduced in both situations. The econometric models derived can also be augmented by including another dependent variable that measures bank rejections/acceptance for bank loans. Such models allow to gauge about discouraged borrowers. The following models are thus considered:

\section{Econometric model for bank acceptance of corporate loans \\ Model 1}

BANK ACCEPTANCE OF LOAN APPLICATION $=\boldsymbol{\lambda}+\theta$ LARGESTCOMPANIES $+\beta S M E+\alpha C G R O U P S+$ $\pi B O N U S$ ISSUE $+\mu$ APPLYLOAN/EQUITY + EXCELIQ $+\varepsilon$ 
Prayagsing, C. C. (2020) Modeling the Behaviour of Corporate Demand for Credit in Mauritius before and after the Global Financial Crisis Under Conditions of Excess Liquidity by Banks Archives of Business Research, 8(5). 63-79.

\section{Model 2}

BANK ACCEPTANCE OF LOAN APPLICATION $=(\lambda+\theta$ LARGESTCOMPANIES $+\beta S M E+\alpha$ CGROUPS + TDEBTREPAYMENT+

$\mu A P P L Y L O A N / E Q U I T Y$

$+\varepsilon_{\mathrm{t}}$

EXCELIQ

\section{Empirical results:}

1. Probability of demand for bank loans before and after the GFC

2. Regression analysis of demand for bank loans application before and after the GFC.

3. Probability of bank loan acceptance of loan applications

4. Regression analysis of bank loan acceptance before and after the GFC

This section provides an empirical analysis of equations 1 to 10 above. The optimal capital structure of a company is the one which minimizes the weighted average cost of capital by taking a mixture of both debt and equity financing. The global phenomenon of the 2008 financial crisis, has however, caused a change in the pattern of the capital structure of companies due to the massive repercussions that it had upon the banking sector and upon the economy. As displayed in Table.2, prior to the crisis, there was a 57\% probability for large companies to apply for bank loans, compared with an $87 \%$ chance of the entities directing towards equity financing. Finance was easily made available to large entities in that instance, considering their size, nature and ease of repayments of such large companies.

As displayed in Table 3, demand for both debt and equity financing was positively influenced by 0.245 respectively in Model 1 . The relationship is further evidenced by a positive 0.33 change in Model 2. Nevertheless, the post-crisis effect rendered board of directors to be more risk averse, henceforth causing companies to shift from debt financing to equity financing. The post-crisis effect, during the 2010 period provides for a downward movement of 0.32 for loan applications, while further advances were made to attract more investors and subsequently, expanding the share capital value by an upward movement of 0.05 . The relationship substantiating the redirection of finance from debt to equity is validated by both models, with the former being positively influenced by approximately $4 \%$ while the latter rising by $5 \%$.

Table 4 provides for the bank's response to the loan applications, while also catering for investors' perception and behavioral action towards equity financing. It can be seen that that prior to the financial crisis, the probability for banks to accept and provide loans to large entities was $52 \%$. Banks were able to lend, considering the adequate credit ratings of large companies, which mostly originated from the manufacturing, construction and hotel industry. Following the crisis however, there was sought to be a negative relationship between applications and acceptance for loans for large companies. As provided in Table 5, the post crisis effect caused bank acceptance to negatively be influenced by 0.254 for every percentage change in loan applications. The crisis hit the banking industry, the result of which had the banking industry, in line with other regulatory bodies implementing further banking regulations. Conversely, as per Model 2, large companies which had an impeccable loan repayment track record also witnessed a massive shift of approximately $32 \%$ in loan financing availability. This was sought to be the case considering that it was the dominant institutions which were held responsible for the market to crash, hence several precautionary measures were taken at bank level prior to provision of loans to institutions. 
Small and Medium Enterprises, on their part, were highly dependent upon equity financing from the beginning. As shown in 2, there was a $56 \%$ chance for a small and medium entity to opt for equity, as opposed to a $23 \%$ probability of applying for a bank loan in 2007. Failure to have acceptable credit ratings to qualify for bank loans can be deemed as the main factor causing the limited number of loan applications. As displayed in Table 3, the demand for bank loans was positively influenced by only 0.045 . Such provides for the limited acceptable credit ratings for SMEs' due to their inability or delay repaying back formerly taken loans from financial institutions. Following the GFC, the demand for loan applications followed a diminishing trend, while that of equity rose and nearly doubled. Table 3 provides for the upward movement from 0.514 to 0.621 for debt financing, with respect to Model 1. Small and Medium enterprises, which had not previously issued bonus shares, would find themselves highly depending on equity financing, as substantiated by a nearly 50\% increase in Table 3. Small and medium enterprises comprised of most manufacturing entities, whose consumers would mostly be the local public. In the post crisis era, the high risk of uncertainty which prevailed, rendered a fall in demand for products, causing a disequilibrium between the demand and supply for same. The mismatch between the two indicated a high level of inventory with shrinking prices for small and medium enterprises. The companies were henceforth unable to repay back the interest rates, prevailing from the previous loans taken. This is further justified by Model 2 which indicates how the failure to repay back previously taken loans influenced the shift towards equity financing.

Prior to the crisis however, bank acceptance towards loans to small and medium enterprises stood at approximately 50\%. As previously explained, small and enterprises failed to qualify for loan applications due to their credit ratings, hence substantiating the nearly significant provision of loan supply to these entities. This was also deemed to be the case, for SMEs' who were influenced by debt repayments, as provided in Model 2. Nevertheless, in 2010, bank acceptance for loans were negatively affected by their prior demands, notably due to SMEs' nature in question, failure to qualify and increasing banking regulations. Entities which were able to repay back their loans however had an advantage as explained by Model 2 in Table 4.

The first model provides that institutions which had recently applied for equity would also cater to have an adequate mixture of both means of financing in their capital structure, henceforth applying for bank loans, at a rate of 1.122. As provided in Table 3, a percentage change in equity would influence loan application by $1.254 \%$. The reverse was also sought to be true as companies which had previously relayed on bank loans nevertheless applied for equity financing in the precrisis era, as a unit change in loan application would implicate that equity application will be altered by 1.65. In 2010 however, following the lack of confidence in the market and in their investments, investors were reluctant to provide more finance to companies. Such caused highly equity-dependent entities to shift towards further debt financing. However, the debt-equity ratio remained within the range, with companies now relaying slightly more upon debt financing, as opposed to equity financing.

While loan application prior to the crisis was positively influenced by $1.254 \%$ for a percentage change in equity application, the reverse was sought to be true in terms of bank loan acceptance. There exists an inverse relationship between equity financing and loan acceptance. In fact, as displayed in Table 4, a percentage change in the demand for equity would cause bank acceptance to negatively be influenced by $0.125 \%$. Following the crisis, entities shifted towards more debt 
Prayagsing, C. C. (2020) Modeling the Behaviour of Corporate Demand for Credit in Mauritius before and after the Global Financial Crisis Under Conditions of Excess Liquidity by Banks Archives of Business Research, 8(5). 63-79.

financing, vis a vis equity financing. Banks were still reluctant to lend to entities, notably due to the strict regulations which prevailed, justifying the negative relationship as displayed in Table 4. It indicates that a 1\% change in loan application would lead to bank rejection by 0.254 in 2010 .

Corporate groups, on their end ensured to have an adequate mix of both means of financing, with a slighter preference for equity in 2007. Investors had a long-term view for the businesses henceforth justifying the preferred choice for equity, as they were mainly concerned with their future benefits out of the entities. As provided in Table 2, there was a $45 \%$ chance for wellestablished corporate groups to opt for equity financing. Demand for loan application was also positively influenced by 0.874 while that of equity application followed an upward trend of 0.547 . Entities which had not previously issued any bonus shares found their application for loans being positively influenced by 1.21 . Conversely, there was a $35 \%$ probability of these very entities applying for bank loans. The proportion for equity financing followed suit by only $0.412 \%$ for every percentage change. However, in 2010, the probability diminished to approximately $20 \%$ as interest rates were deemed high and mostly due to the uncertainty of relying on the banking industry and financial market. Established corporate groups were the entities mostly affected by the crisis. The entities entailed high level projects, which required high level of investments, which were partly heavily funded through bank loans. The market crash rendered a massive fall in share prices of listed entities, putting them in a position whereupon they were unable to raise further capital through means of bank loans. The application for debt financing fell by $15 \%$ as provided in Model 1. The high level of debt to be repaid also caused a downfall in loan application as supported by Model 2. Contrariwise, the diminishing value of shares, attracted further investors, hence justifying the rising trend in equity financing, as displayed in table 3 , from 0.547 to 0.624 in a case where bonus issues influenced the model. With debt repayment being a contributing factor to the model, it can be sought that equity still rose by $11 \%$.

Corporate entities relied heavily on equity financing, with only approximately $35 \%$ applying for bank loans. However, the 35\% comprised of large groups which would require high level of financing, for high risk high return projects. There existed a negative relationship between the application for such loans by corporate entities and the banks' acceptance, notably because of the level of financing required. Additionally, loans for long term projects would quite possibly hinder the banks' functionality and liquidity in the short run. The crisis did nothing but worsened the availability of loans to such entities as the regulatory measures which prevailed were strict and did not encourage loan facilities for all categories of activities. A tedious process was set in place, and severe conditions were attached to loan provisions. However, well established corporate entities which maintained their credit ratings and had significant or no effect post-crisis did meet the loan requirements and facilities were provided for such entities. The demand for debt financing positively influenced bank acceptance for same by $0.254 \%$ in 2010 .

Model 1 caters for Bonus issue as an independent variable in our study. Bonus issues are given, to attract further investors to the business, henceforth increasing the equity base. Prior to the crisis, the probability for entities offering bonus issues to apply for loans was negatively influenced by 1.254. The inverse relationship between the two is simplified by the fact that the issuance of bonus shares, instead of paying cash dividends, would make financial institutions perceive the companies, as facing major liquidity issues. Such would in turn render Companies unable to qualify for loans. On the other hand, the issuance of bonus shares would automatically attract more investors, 
henceforth the variable had little or no significant influence on equity application. Following the crisis however, such entities, which were already deemed as facing liquidity issues, would find their conditions worsen and hence further be ineligible for loans as bank loan applications would now be negatively worsened by $1.847 \%$. This would re-direct institutions to move towards more equity financing, but prevailing liquidity issues would cause demand for equity to be nearly insignificant.

Model 2, on its part considers debt repayment, as one major influencing factor of the demand for credit pre and post financial crisis. Entities which had previously undertaken bank loans, would find an inverse relationship between debt repayment and further loan applications. The inability to repay back loans in a timely manner would render entities not to qualify for loans, thereby explaining the inverse link between the two, as provided in Table 2 . In fact, failure to pay previously owed loans influenced the loan applications negatively by 0.231 . High level of debt would also indicate a liquidity issue in the companies, which would discourage investors from investing in the entities. This is further substantiated by the negative link between debt repayment and equity finance application, as displayed in the table whereupon there exists a negative $0.524 \%$ change for every percentage change in debt repayment. In 2010, companies which were already facing major liquidity and debt repayment issues, would find their situation worsen, as the crisis caused interest rates to look greater than their actual value, due to the rising rates.

Both models cater for the relationship between bank rejects and loan applications. As provided in Table 2, prior loan applications rejection would not discourage entities from applying for further loans following the crisis. The probability for companies which had previously applied for loans and fail to obtain one yet re- apply for loans following the crisis was $85 \%$ in both cases. As per Model 1, entities which were not influenced by the need to repay back loans, found a positive relationship of 2.28 towards loan applications. There also existed an upward trend between debt repayment and loan application in Model 2, but same was highly influenced by the fact that previously loans had to be repaid.

Prior to the financial crisis, companies, irrespective of their size and nature, ensured to have an optimal mix of both means of financing, with corporate entities having a slight preference for equity while small and medium enterprises relying heavily on startup business loans. Institutions which relayed on equity financing would also nevertheless apply for loan facilities, in the light of minimizing the weighted average cost of capital. Companies with high level of debt repayments compounded those which had previously issued bonus shares found hiccups in availing bank loan facilities. As the crisis hit the economy, and directly affected the banking industry, increasing banking regulations and supervision caused more precautionary measures, which ultimately led to strict regulations and limited access to finance. Such caused large entities and small and medium enterprises to shift more towards equity financing. Finance, was nevertheless still made available to entities which had an impeccable repayment track record and to those which had maintained their credits prior to, during and after the crisis. 
Prayagsing, C. C. (2020) Modeling the Behaviour of Corporate Demand for Credit in Mauritius before and after the Global Financial Crisis Under Conditions of Excess Liquidity by Banks Archives of Business Research, 8(5). 63-79.

\section{Table 2: Probit models for demand for finance: Marginal Effects}

\begin{tabular}{|c|c|c|c|c|c|c|c|c|}
\hline & \multicolumn{4}{|c|}{ Model 1} & \multicolumn{4}{|c|}{ Model 2} \\
\hline & $\begin{array}{c}\text { Before } \\
\text { Fin Crisis }\end{array}$ & $\begin{array}{l}\text { After Fin } \\
\text { Crisis }\end{array}$ & $\begin{array}{l}\text { Before } \\
\text { Fin } \\
\text { Crisis }\end{array}$ & $\begin{array}{l}\text { After Fin } \\
\text { Crisis }\end{array}$ & $\begin{array}{c}\text { Before } \\
\text { Fin Crisis }\end{array}$ & $\begin{array}{l}\text { After Fin } \\
\text { Crisis }\end{array}$ & $\begin{array}{l}\text { Before } \\
\text { Fin } \\
\text { Crisis }\end{array}$ & $\begin{array}{c}\text { After Fin } \\
\text { Crisis }\end{array}$ \\
\hline & $\begin{array}{l}\text { Apply } \\
\text { Loan } \\
2007 \\
\end{array}$ & $\begin{array}{l}\text { Apply } \\
\text { loan } \\
2010 \\
\end{array}$ & $\begin{array}{l}\text { Apply } \\
\text { Equity } \\
2007 \\
\end{array}$ & $\begin{array}{l}\text { Apply } \\
\text { Equity } \\
2010 \\
\end{array}$ & $\begin{array}{l}\text { Apply } \\
\text { Loan } \\
2007 \\
\end{array}$ & $\begin{array}{l}\text { Apply } \\
\text { loan } \\
2010 \\
\end{array}$ & $\begin{array}{l}\text { Apply } \\
\text { Equity } \\
2007\end{array}$ & $\begin{array}{l}\text { Apply } \\
\text { Equity } \\
2010\end{array}$ \\
\hline \multicolumn{9}{|c|}{ Firm-Characteristics Variable } \\
\hline $\begin{array}{c}\text { Largest } \\
\text { companies }\end{array}$ & $\begin{array}{c}0.57 \\
(3.24)\end{array}$ & $\begin{array}{c}0.25 \\
(4.21)\end{array}$ & $\begin{array}{c}0.87 \\
(3.25)\end{array}$ & $\begin{array}{c}0.92 \\
(4.63)\end{array}$ & $\begin{array}{l}0.254 \\
(5.21)\end{array}$ & $\begin{array}{l}0.014 \\
(2.95)\end{array}$ & $\begin{array}{c}0.245 \\
(4.874)\end{array}$ & $\begin{array}{l}0.358 \\
(5.18)\end{array}$ \\
\hline SMEs & $\begin{array}{c}0.23 \\
(4.87)\end{array}$ & $\begin{array}{c}0.18 \\
(2.97)\end{array}$ & $\begin{array}{c}0.56 \\
(3.65)\end{array}$ & $\begin{array}{c}0.95 \\
(3.98)\end{array}$ & $\begin{array}{c}0.65 \\
(5.14)\end{array}$ & $\begin{array}{l}0.314 \\
(4.57)\end{array}$ & $\begin{array}{l}0.145 \\
(6.24)\end{array}$ & $\begin{array}{l}0.524 \\
(5.32)\end{array}$ \\
\hline $\begin{array}{c}\text { Apply } \\
\text { Loan/Apply } \\
\text { Equity }\end{array}$ & $\begin{array}{l}1.122 \\
(3.21)\end{array}$ & $\begin{array}{l}1.752 \\
(4.21)\end{array}$ & $\begin{array}{l}0.9524 \\
(5.32)\end{array}$ & $\begin{array}{l}0.8412 \\
(3.547)\end{array}$ & $\begin{array}{c}1.25 \\
(3.84)\end{array}$ & $\begin{array}{c}1.85 \\
(4.07)\end{array}$ & $\begin{array}{c}0.524 \\
(2.985)\end{array}$ & $\begin{array}{l}0.041 \\
(3.05)\end{array}$ \\
\hline Corporate group & $\begin{array}{l}0.354 \\
(2.89)\end{array}$ & $\begin{array}{l}0.198 \\
(3.52)\end{array}$ & $\begin{array}{c}0.45 \\
(4.65)\end{array}$ & $\begin{array}{c}0.87 \\
(3.05)\end{array}$ & $\begin{array}{l}0.054 \\
(2.87)\end{array}$ & $\begin{array}{c}0.001 \\
(3.025)\end{array}$ & $\begin{array}{l}0.442 \\
(4.06)\end{array}$ & $\begin{array}{l}0.635 \\
(5.04)\end{array}$ \\
\hline Bonus Issue & $\begin{array}{c}3.78 \\
(4.12)\end{array}$ & $\begin{array}{c}6.25 \\
(3.65)\end{array}$ & $\begin{array}{l}0.535 \\
(3.24)\end{array}$ & $\begin{array}{l}0.825 \\
(2.96)\end{array}$ & & & & \\
\hline Debt Repayment & & & & & $\begin{array}{l}-0.254 \\
(3.05)\end{array}$ & $\begin{array}{l}-0.465 \\
(2.98)\end{array}$ & $\begin{array}{l}-5.65 \\
(4.21)\end{array}$ & $\begin{array}{l}-4.32 \\
(3.58)\end{array}$ \\
\hline $\begin{array}{c}\text { Bank rejects } \\
2007\end{array}$ & & $\begin{array}{l}0.854 \\
(3.84)\end{array}$ & & & & $\begin{array}{l}0.854 \\
(4.12)\end{array}$ & & \\
\hline
\end{tabular}

t statistics in brackets.

Source: Author's Calculations

Multivariate Probit regression results of bank loan applications before and after the GFC 
Table 3: Estimated Probit Regression coefficients for demand for finance models

\begin{tabular}{|c|c|c|c|c|c|c|c|c|}
\hline & \multicolumn{4}{|c|}{ Model 1} & \multicolumn{4}{|c|}{ Model 2} \\
\hline & $\begin{array}{l}\text { Before } \\
\text { Finan } \\
\text { Crisis }\end{array}$ & $\begin{array}{l}\text { After Fina } \\
\text { Crisis }\end{array}$ & $\begin{array}{l}\text { Before } \\
\text { Finan } \\
\text { Crisis }\end{array}$ & $\begin{array}{l}\text { After } \\
\text { Financ } \\
\text { Crisis }\end{array}$ & $\begin{array}{l}\text { Before } \\
\text { Financ } \\
\text { Crisis }\end{array}$ & $\begin{array}{l}\text { After } \\
\text { Finan } \\
\text { Crisis }\end{array}$ & $\begin{array}{l}\text { Before } \\
\text { Finan } \\
\text { Crisis }\end{array}$ & $\begin{array}{l}\text { After } \\
\text { Financ } \\
\text { Crisis }\end{array}$ \\
\hline & $\begin{array}{l}\text { Apply } \\
\text { Loan } \\
2007 \\
\end{array}$ & $\begin{array}{l}\text { Apply loan } \\
2010\end{array}$ & $\begin{array}{l}\text { Apply } \\
\text { Equity } \\
2007 \\
\end{array}$ & $\begin{array}{l}\text { Apply } \\
\text { Equity } \\
2010\end{array}$ & $\begin{array}{c}\text { Apply Loaı } \\
2007\end{array}$ & $\begin{array}{l}\text { Apply loan } \\
2010\end{array}$ & $\begin{array}{l}\text { Apply } \\
\text { Equity } \\
2007 \\
\end{array}$ & $\begin{array}{c}\text { Apply } \\
\text { Equity } \\
2010 \\
\end{array}$ \\
\hline \multicolumn{9}{|c|}{ Firm Characteristic Variable } \\
\hline SMEs & $\begin{array}{l}0.254 \\
(2.52)\end{array}$ & $\begin{array}{l}0.365 \\
(2.85)\end{array}$ & $\begin{array}{l}0.514 \\
(4.52)\end{array}$ & $\begin{array}{l}0.621 \\
(3.25)\end{array}$ & $\begin{array}{l}0.045 \\
(5.24)\end{array}$ & $\begin{array}{c}0.024 \\
(3.014)\end{array}$ & $\begin{array}{r}0.147 \\
(6.21)\end{array}$ & $\begin{array}{l}0.654 \\
(4.87)\end{array}$ \\
\hline $\begin{array}{c}\text { Apply } \\
\text { Loan/Equit } \\
y\end{array}$ & $\begin{array}{l}1.254 \\
(3.14)\end{array}$ & $\begin{array}{c}1.24 \\
(3.02)\end{array}$ & $\begin{array}{c}1.65 \\
(2.91)\end{array}$ & $\begin{array}{c}1.57 \\
(2.75)\end{array}$ & $\begin{array}{c}0.338 \\
(63.54)\end{array}$ & $\begin{array}{l}0.486 \\
(4.58)\end{array}$ & $\begin{array}{l}0.685 \\
(4.54)\end{array}$ & $\begin{array}{l}0.828 \\
(6.24)\end{array}$ \\
\hline $\begin{array}{c}\text { Corporate } \\
\text { group }\end{array}$ & $\begin{array}{l}0.874 \\
(5.68)\end{array}$ & $\begin{array}{l}0.658 \\
(5.47)\end{array}$ & $\begin{array}{l}0.547 \\
(4.87)\end{array}$ & $\begin{array}{l}0.624 \\
(2.95)\end{array}$ & $\begin{array}{c}1.21 \\
(2.85)\end{array}$ & $\begin{array}{l}0.952 \\
(3.02)\end{array}$ & $\begin{array}{c}0.412 \\
(4.056)\end{array}$ & $\begin{array}{c}0.524 \\
(4.068)\end{array}$ \\
\hline $\begin{array}{l}\text { Bonus } \\
\text { Issue }\end{array}$ & $\begin{array}{l}-1.254 \\
(3.57) \\
\end{array}$ & $\begin{array}{l}-1.847 \\
(2.87) \\
\end{array}$ & $\begin{array}{c}-2.54 \\
(4.42)\end{array}$ & $\begin{array}{l}-0.417 \\
(6.98) \\
\end{array}$ & & & & \\
\hline $\begin{array}{c}\text { Debt } \\
\text { Repayment }\end{array}$ & & & & & $\begin{array}{c}-0.231 \\
(6.214)\end{array}$ & $\begin{array}{c}-0.524 \\
(5.952)\end{array}$ & $\begin{array}{l}-0.524 \\
(5.78)\end{array}$ & $\begin{array}{l}-0.325 \\
(4.78)\end{array}$ \\
\hline $\begin{array}{c}\text { Bank } \\
\text { rejects } \\
2007 \\
\end{array}$ & & $\begin{array}{c}2.28 \\
(4.42)\end{array}$ & & & & $\begin{array}{c}0.524 \\
(3.654)\end{array}$ & & \\
\hline Constant & $\begin{array}{l}-2.55 \\
(2.54)\end{array}$ & $\begin{array}{l}-6.52 \\
(2.47)\end{array}$ & $\begin{array}{l}-0.45 \\
(3.24)\end{array}$ & $\begin{array}{l}-0.35 \\
(2.66)\end{array}$ & $\begin{array}{l}-1.165 \\
(2.54)\end{array}$ & $\begin{array}{l}-0.877 \\
(3.02)\end{array}$ & $\begin{array}{l}-0.729 \\
(5.14)\end{array}$ & $\begin{array}{l}-0.832 \\
(1.19)\end{array}$ \\
\hline \multicolumn{9}{|c|}{ Sectoral Dummy Variables } \\
\hline Banking & $\begin{array}{l}-0.081 \\
(3.16)\end{array}$ & $\begin{array}{l}-0.275 \\
(5.47)\end{array}$ & $\begin{array}{c}0.340 \\
(3.128)\end{array}$ & $\begin{array}{c}0.182 \\
(3.125)\end{array}$ & $\begin{array}{l}-0.125 \\
(1.98)\end{array}$ & $\begin{array}{l}-0.335 \\
(2.05)\end{array}$ & $\begin{array}{c}-0.23 \\
(4.25)\end{array}$ & $\begin{array}{l}-0.266 \\
(1.89)\end{array}$ \\
\hline Insurance & $\begin{array}{l}-0.187 \\
(3.25)\end{array}$ & $\begin{array}{l}-0.089 \\
(4.25)\end{array}$ & $\begin{array}{c}0.408 \\
(3.076)\end{array}$ & $\begin{array}{c}0.315 \\
(2.824) \\
\end{array}$ & $\begin{array}{l}-0.654 \\
(2.05)\end{array}$ & $\begin{array}{l}-0.914 \\
(3.25)\end{array}$ & $\begin{array}{l}-0.054 \\
(1.99)\end{array}$ & $\begin{array}{l}-0.548 \\
(4.05)\end{array}$ \\
\hline Leasing & $\begin{array}{c}-0.025 \\
(2.98)\end{array}$ & $\begin{array}{l}-0.116 \\
(6.74)\end{array}$ & $\begin{array}{c}0.158 \\
(2.874)\end{array}$ & $\begin{array}{c}0.113 \\
(3.624)\end{array}$ & $\begin{array}{l}-0.242 \\
(2.28)\end{array}$ & $\begin{array}{l}-0.248 \\
(5.21)\end{array}$ & $\begin{array}{l}-1.577 \\
(1.82)\end{array}$ & $\begin{array}{l}-0.236 \\
(1.96)\end{array}$ \\
\hline Hotel & $\begin{array}{l}-0.158 \\
(4.25)\end{array}$ & $\begin{array}{l}-0.165 \\
(2.87)\end{array}$ & $\begin{array}{l}0.370 \\
(6.18)\end{array}$ & $\begin{array}{l}0.287 \\
(3.78)\end{array}$ & $\begin{array}{l}-0.024 \\
(2.04)\end{array}$ & $\begin{array}{l}-0.065 \\
(1.98)\end{array}$ & $\begin{array}{l}-0.087 \\
(2.58)\end{array}$ & $\begin{array}{l}-0.089 \\
(2.78)\end{array}$ \\
\hline $\begin{array}{c}\text { Manufactur } \\
\text { ing }\end{array}$ & $\begin{array}{l}-0.733 \\
(3.87)\end{array}$ & $\begin{array}{l}-0.266 \\
(3.95)\end{array}$ & $\begin{array}{l}0.788 \\
(2.69)\end{array}$ & $\begin{array}{l}0.184 \\
(4.58)\end{array}$ & $\begin{array}{l}-0.281 \\
(4.58)\end{array}$ & $\begin{array}{l}-1.898 \\
(3.05)\end{array}$ & $\begin{array}{l}-0.221 \\
(2.26)\end{array}$ & $\begin{array}{l}-0.116 \\
(3.68)\end{array}$ \\
\hline $\begin{array}{c}\text { Retail/Dist } \\
\text { ributive }\end{array}$ & $\begin{array}{l}-0.235 \\
(7.24) \\
\end{array}$ & $\begin{array}{l}-0.230 \\
(4.68)\end{array}$ & $\begin{array}{l}0.443 \\
(2.78) \\
\end{array}$ & $\begin{array}{l}0.362 \\
(2.82) \\
\end{array}$ & $\begin{array}{l}-0.054 \\
(2.14)\end{array}$ & $\begin{array}{l}-0.078 \\
(2.87) \\
\end{array}$ & $\begin{array}{l}-0.036 \\
(3.35)\end{array}$ & $\begin{array}{l}-0.048 \\
(4.25) \\
\end{array}$ \\
\hline $\begin{array}{c}\text { Constructio } \\
\mathbf{n}\end{array}$ & $\begin{array}{c}-0.254 \\
(3.54)\end{array}$ & $\begin{array}{c}-0.541 \\
(6.52)\end{array}$ & $\begin{array}{l}0.047 \\
(4.54)\end{array}$ & $\begin{array}{l}0.054 \\
(5.32)\end{array}$ & $\begin{array}{l}-0.215 \\
(2.18)\end{array}$ & $\begin{array}{l}-0.47 \\
(2.28)\end{array}$ & $\begin{array}{l}-0.158 \\
(4.52)\end{array}$ & $\begin{array}{l}-0.296 \\
(1.96)\end{array}$ \\
\hline $\begin{array}{c}\text { Log } \\
\text { Likelihood } \\
\end{array}$ & -512.22 & -417.54 & -490.65 & -92.54 & -200.15 & -325.14 & -158.65 & -125.14 \\
\hline$\chi 2$ & 45.52 & 62.25 & 45.14 & 58.14 & 47.12 & 45.21 & 52.36 & 54.69 \\
\hline Sig & 0.00 & 0.00 & 0.00 & 0.00 & 0.00 & 0.00 & 0.00 & 0.00 \\
\hline
\end{tabular}


Prayagsing, C. C. (2020) Modeling the Behaviour of Corporate Demand for Credit in Mauritius before and after the Global Financial Crisis Under Conditions of Excess Liquidity by Banks Archives of Business Research, 8(5). 63-79.

Multivariate regressions of alternative Probit models. Dummy variable equals 1 if firms applied for loans, 0 otherwise.

$t$ statistics in brackets

Source: Author's Calculations

Table 4: Probit models for Bank Acceptance for bank loans: Marginal effects

\begin{tabular}{|c|c|c|c|c|}
\hline & \multicolumn{2}{|c|}{ Model 1} & \multicolumn{2}{|c|}{ Model 2} \\
\hline & $\begin{array}{c}\text { Bank Acceptance } \\
\text { in } 2007 \\
\end{array}$ & $\begin{array}{c}\text { Bank Acceptance } \\
\text { in } 2010 \\
\end{array}$ & $\begin{array}{c}\text { Bank Acceptance } \\
\text { in } 2007 \\
\end{array}$ & $\begin{array}{c}\text { Bank Acceptance in } \\
2010 \\
\end{array}$ \\
\hline \multicolumn{5}{|c|}{ Firm-Characteristics Variable } \\
\hline Largest companies & $\begin{array}{c}0.052 \\
(3.182) \\
\end{array}$ & $\begin{array}{c}0.002 \\
(2.012) \\
\end{array}$ & $\begin{array}{c}0.325 \\
(2.956) \\
\end{array}$ & $\begin{array}{l}0.0014 \\
(4.125) \\
\end{array}$ \\
\hline SMEs & $\begin{array}{c}0.478 \\
(4.125)\end{array}$ & $\begin{array}{c}0.001 \\
(1.968)\end{array}$ & $\begin{array}{c}0.457 \\
(5.214)\end{array}$ & $\begin{array}{l}0.0125 \\
(5.214)\end{array}$ \\
\hline $\begin{array}{c}\text { Apply } \\
\text { Loan/Equity }\end{array}$ & $\begin{array}{c}0.112 \\
(4.052)\end{array}$ & $\begin{array}{l}0.0145 \\
(2.364)\end{array}$ & $\begin{array}{l}0.524 \\
(2.84) \\
\end{array}$ & $\begin{array}{l}0.0578 \\
(3.021)\end{array}$ \\
\hline Corporate group & $\begin{array}{c}0.245 \\
(3.012) \\
\end{array}$ & $\begin{array}{c}0.021 \\
(2.842) \\
\end{array}$ & $\begin{array}{c}0.124 \\
(2.789) \\
\end{array}$ & $\begin{array}{l}0.0214 \\
(5.214) \\
\end{array}$ \\
\hline Bonus Issue & $\begin{array}{c}0.325 \\
(3.286) \\
\end{array}$ & $\begin{array}{c}0.528 \\
(3.154) \\
\end{array}$ & & \\
\hline Debt Repayment & & & $\begin{array}{c}0.365 \\
(6.214)\end{array}$ & $\begin{array}{c}0.102 \\
(3.242)\end{array}$ \\
\hline $\begin{array}{c}\text { EXCESS } \\
\text { LIQUIDITY }\end{array}$ & $\begin{array}{l}0.546 \\
(3.54)\end{array}$ & $\begin{array}{l}0.025 \\
(2.65)\end{array}$ & $\begin{array}{l}0.635 \\
(4.25)\end{array}$ & $\begin{array}{l}0.117 \\
(2.87)\end{array}$ \\
\hline
\end{tabular}

t statistics in brackets

Source: Author's Calculations 
Table.5: Probit models for Bank Acceptance for bank loans: Probit Regression results

\begin{tabular}{|c|c|c|c|c|}
\hline & \multicolumn{2}{|c|}{ Model 1} & \multicolumn{2}{|c|}{ Model 2} \\
\hline & $\begin{array}{c}\text { Bank Acceptance in } \\
2007 \\
\end{array}$ & $\begin{array}{c}\text { Bank Acceptance in } \\
2010 \\
\end{array}$ & $\begin{array}{c}\text { Bank Acceptance in } \\
2007 \\
\end{array}$ & $\begin{array}{c}\text { Bank Acceptance in } \\
2010 \\
\end{array}$ \\
\hline \multicolumn{5}{|c|}{ Firm-Characteristics Variable } \\
\hline Largest companies & $\begin{array}{l}-0.085 \\
(-3.25) \\
\end{array}$ & $\begin{array}{l}-0.254 \\
(-5.02) \\
\end{array}$ & $\begin{array}{l}-0.325 \\
(-2.21) \\
\end{array}$ & $\begin{array}{l}-0.415 \\
(-3.54) \\
\end{array}$ \\
\hline SMES & $\begin{array}{l}0.054 \\
(2.01) \\
\end{array}$ & $\begin{array}{l}0.041 \\
(3.54) \\
\end{array}$ & $\begin{array}{l}0.065 \\
(4.02) \\
\end{array}$ & $\begin{array}{l}0.078 \\
(3.25) \\
\end{array}$ \\
\hline Apply Loan/Equity & $\begin{array}{l}-0.125 \\
(-1.98) \\
\end{array}$ & $\begin{array}{l}-0.214 \\
(-4.21) \\
\end{array}$ & $\begin{array}{l}-0.632 \\
(-4.87)\end{array}$ & $\begin{array}{l}-0.214 \\
(-7.18)\end{array}$ \\
\hline Corporate group & $\begin{array}{l}0.145 \\
(6.25) \\
\end{array}$ & $\begin{array}{l}0.254 \\
(4.36) \\
\end{array}$ & $\begin{array}{r}0.541 \\
(5.47) \\
\end{array}$ & $\begin{array}{r}0.874 \\
(4.58) \\
\end{array}$ \\
\hline Bonus Issue & $\begin{array}{l}-0.325 \\
(-3.78) \\
\end{array}$ & $\begin{array}{l}-0.125 \\
(-5.78) \\
\end{array}$ & & \\
\hline Debt Repayment & & & $\begin{array}{l}0.652 \\
(6.74) \\
\end{array}$ & $\begin{array}{l}0.654 \\
(5.98) \\
\end{array}$ \\
\hline EXCESS LIQUIDITY & $\begin{array}{l}-0.847 \\
(-0.25) \\
\end{array}$ & $\begin{array}{c}-0.635 \\
(-0.028) \\
\end{array}$ & $\begin{array}{c}-0.478 \\
(-0.587) \\
\end{array}$ & $\begin{array}{c}-0.985 \\
(-0.752) \\
\end{array}$ \\
\hline Constant & 0.112 & 0.214 & 0.625 & 0.475 \\
\hline \multicolumn{5}{|c|}{ Sectoral Dummy Variables } \\
\hline Banking & $\begin{array}{c}0.025 \\
(0.725) \\
\end{array}$ & $\begin{array}{c}0.054 \\
(0.952) \\
\end{array}$ & $\begin{array}{c}0.015 \\
(1.152) \\
\end{array}$ & $\begin{array}{c}0.705 \\
(4.125) \\
\end{array}$ \\
\hline Insurance & $\begin{array}{c}0.521 \\
(0.854) \\
\end{array}$ & $\begin{array}{l}-0.365 \\
(0.325) \\
\end{array}$ & $\begin{array}{c}0.014 \\
(1.215) \\
\end{array}$ & $\begin{array}{c}0.524 \\
(2.854) \\
\end{array}$ \\
\hline Leasing & $\begin{array}{c}0.014 \\
(0.654) \\
\end{array}$ & $\begin{array}{l}-0.484 \\
(0.412)\end{array}$ & $\begin{array}{c}0.365 \\
(0.978) \\
\end{array}$ & $\begin{array}{l}00.547 \\
(3.541)\end{array}$ \\
\hline Hotel & $\begin{array}{l}-0.014 \\
(0.841)\end{array}$ & $\begin{array}{c}0.548 \\
(0.752)\end{array}$ & $\begin{array}{c}0.214 \\
(0.035) \\
\end{array}$ & $\begin{array}{c}0.214 \\
(2.854)\end{array}$ \\
\hline Manufacturing & $\begin{array}{c}0.054 \\
(0.714) \\
\end{array}$ & $\begin{array}{c}-0.652 \\
(0.415) \\
\end{array}$ & $\begin{array}{c}0.021 \\
(0.541) \\
\end{array}$ & $\begin{array}{l}0.688 \\
(3.14) \\
\end{array}$ \\
\hline Retail/Distributive & $\begin{array}{c}0.054 \\
(0.745) \\
\end{array}$ & $\begin{array}{l}-0.514 \\
(0.658)\end{array}$ & $\begin{array}{l}0.035 \\
(1.45) \\
\end{array}$ & $\begin{array}{l}0.214 \\
(7.15)\end{array}$ \\
\hline Construction & $\begin{array}{l}0.048 \\
(1.54) \\
\end{array}$ & $\begin{array}{l}-0.145 \\
(1.24)\end{array}$ & $\begin{array}{c}0.658 \\
(3.541) \\
\end{array}$ & $\begin{array}{l}0.524 \\
(2.21)\end{array}$ \\
\hline Log Likelihood & -145.32 & -125.214 & -175.12 & -164.25 \\
\hline$\chi 2$ & 14.09 & 16.52 & 17.21 & 14.25 \\
\hline Sig & 0.02 & 0.07 & 0.08 & 0.09 \\
\hline
\end{tabular}

Multivariate regressions of alternative Probit models. Dummy variable equals 1 if firms' demand for bank loans were successful, 0 if refused. t- statistics in parentheses

One important analysis made is the influence of excess liquidity in the banking system and its influence on demand for bank loans and probability of successful applications. It is observed that the level of excess liquidity held by banks has been on the rise over the year 2009, recording an amount of above 12 billion in 2009, 16 billion in 2012 and 22 billion in 2016. Prior to the GFC in 2008 , the amount of excess liquidity was at a manageable level. As per various Country Reports issued by the IMF, excess liquidity in the banking system culminates to various problems in the economy such as preventing market clearing interest rates and generating disequilibrium between the policy rate (Key Repo Rate for Mauritius) and banks; Prime Lending Rates. As per the regression results from the Bank Acceptance model, it is observed that, for both model 1 and 2, the marginal effects for bank acceptance of loans decreases considerably after the GFC, even with an 
Prayagsing, C. C. (2020) Modeling the Behaviour of Corporate Demand for Credit in Mauritius before and after the Global Financial Crisis Under Conditions of Excess Liquidity by Banks Archives of Business Research, 8(5). 63-79.

increasing amount of excess liquidity held by banks. The regression results in table 5 confirm an insignificant effect of excess liquidity of banks on their acceptance for corporate demand for loans. This reinforces the fact that banks have strengthened their risk appetite following the GFC. Even with excess liquidity in their Books, they have been very prudent in their lending behavior and did not accept risky projects. Hence, following the GFC, a decline in bank loans is noted.

\section{CONCLUSION}

It can be found from the analysis that the global financial crisis has had a major influence in altering the pattern and subsequent demand for corporate finance in both Model 1 and Model 2. The former deems bonus issuance as a key factor which influences the demand and supply for both debt and equity financing while the latter considers the debt repayment variable of upmost essence to loan application and provision responses. Large companies, comprising of entities falling under the wing of the manufacturing, industrial and retail sector found ease in obtaining bank loans prior to the crisis due to the positive rating and nature of their respective businesses. These entities nevertheless minimized their cost of capital through also having an adequate mixture of equity financing as source of capital. Conversely, small and medium enterprises found themselves relaying heavily on startup loans, of limited amounts, as they failed to qualify for greater loan applications due to their inability to meet the adequate requirements. Corporate entities on their end, had a much greater preference for equity financing prior to the crisis. The aftermath of the crisis nevertheless negatively influenced the pattern of financing for all categories of businesses. A more regulated framework was adopted by banks, on an international level which caused banks to be more cautious and limited in providing finance to entities. Adequate risk management procedures, credit rating evaluations and strict compliance procedures have all contributed to a diminishing supply of loan facilities to both large entities and smaller ones, and henceforth, institutions have been gradually embracing equity financing as their major source of funding, with the hope that such means of financing will not cause a future market crash, but rather promote the smooth running of the financial market and the economy. Even with excess liquidity, banks have declined demand for bank loans.

\section{References}

Barclay, M.J., and Smith J.r., 1996. On Financial Architecture: Leverage, Maturity and Priority. Journal of Applied Corporate Finance, 8 (4), 4-17.

BRADLEY, M., JARELL, G., AND KIM, E., 1984. On the Existence of an Optimal Capital structure: Theory and Evidence. Journal of Finance, 39 (3), 857-878.

DURAND, D., 1959. The Cost of Debt and Equity Funds for Business: Trends and Problems of Measurement. In: E. Salomon, ed. The Management of Corporate Capital, New York: The Free Press.

FRIEND, I., AND LANG, L.H., 1988. An Empirical Test of the Impact of Managerial Self-Interest on Corporate Capital Structure. Journal of Finance, 43 (2), 271-281.

HAMID, J., AND SINGH, A., 1992. Corporate Financial Structures in Developing Countries. IFC Technical Paper, 1. International Finance Corporation, Washington, DC.

HASSBROEK. M., 2017. The Impact of the Global Financial Crisis on China's Banking Sector. The Journal of Asian Studies, 35(1).

HONOHAN, P., 2009.Cause and Effect of Financial Access: Cross-country Evidence from The Finscope Surveys. Department of Economics and Institute for International Integration Studies, Trinity College Dublin, 1-28. 
JENSEN, M.C., AND MECKLING, W.H., 1976. Theory of the Firm: Managerial Behaviors, Agency Costs and Ownership Structure. Journal of Financial Economics. 3(4), 305-360.

JORDAN, J., LOWE, J., AND TAYLOR, P., 1998.Strategy and Financial Policy in UK and Small firms. Journal of Business Finance and Accounting, 25 (1), 1-27.

KESTER, C.W., 1986. Capital and Ownership structure: A Comparison of United States and Japanese Manufacturing Corporations. Financial Management, 15 (1), 5-16.

MACH, T., AND WOLKEN, J.D., 2012. Examining the Impact of Credit Access on Small Firm Survivability. FEDS Working Paper, 1-39.

MODIGLIANI, F., AND MILLER, M.H., 1958. The Cost of Capital, Corporate Finance and the theory of Investment. American Economic Review, 48, 261-297.

MODIGLIANI, F., AND MILLER, M.H., 1963. Corporate Income Taxes and the Cost of Capital: A Correction. American Economic Review, 53, 433-443.

MYERS, S.C., 1984. The Capital Structure Puzzle. Journal of Finance, 39 (1), 575-592.

MYERS, S., AND MAJLUF, N., 1984. Corporate Financing and Investment Decisions When Firms have Information that Investors do not have. Journal of financial Economics, 20, 237-265.

RAJAN, R., AND ZINGALES, L., 1995. What do we Know about Capital Structure? Some evidence from International Data. Journal of Finance, 50, 1421-1460.

ROSS, S., 1977. The Determination of Financial Structures: An Incentive Signaling Approach. The Bell Journal of Economics, 8 (1), 23-40.

STIGLITZ, J.E., AND WEISS, A., 1981. Credit Rationing in Markets with Imperfect Information. American Economic Review, 71 (3), 393-410.

UDELL.G.F, 2009. Bank Market Power and SME Financing Constraints. Review of Finance, 13(2), 309-340.

WESTON, J.F., AND BRIGHAM, E.F., 1981.Managerial finance, 7th Edition. Hinsdale: Dryden Press. 